\title{
Brazilian canine hepatozoonosis
}

\author{
Hepatozoonose canina brasileira \\ Lucia Helena O’Dwyer \\ Department of Parasitology, Institute of Biosciences, Universidade Estadual Paulista - UNESP \\ Received August 10, 2010 \\ Accepted May 12, 2011
}

\begin{abstract}
The genus Hepatozoon includes hundreds of species that infect birds, reptiles, amphibians and mammals, in all continents with tropical and subtropical climates. Two species have been described in domestic dogs: H. canis, reported in Europe, Asia, Africa, South America and the United States; and H. americanum, which so far has only been diagnosed in the United States. In Brazil, the only species found infecting dogs is $H$. canis. The objective of this review was to detail some aspects of canine hepatozoonosis, caused by $H$. canis, and the main points of its biology, transmission, pathogenicity, symptoms, epidemiology and diagnostic methods, with emphasis on research developed in Brazil.
\end{abstract}

Keywords: Hepatozoon canis, dogs, infection, revision, Brazil.

\section{Resumo}

O gênero Hepatozoon compreende centenas de espécies que infectam aves, répteis, anfíbios e mamíferos, em todos os continentes de clima tropical e subtropical. No cão doméstico duas espécies são descritas, $H$. canis e H. americanum; a primeira presente na Europa, Ásia, África, América do Sul e nos Estados Unidos da América do Norte (EUA), e a segunda, diagnosticada até o momento somente nos EUA. No Brasil, a espécie que infecta o cão foi caracterizada como H. canis. Esta revisão objetiva detalhar alguns aspectos da hepatozoose canina, causada pelo $H$. canis e principais pontos de biologia, transmissão, patogenia e sintomas, epidemiologia e métodos de diagnóstico, enfatizando as pesquisas desenvolvidas no Brasil.

Palavras-chave: Hepatozoon canis, cães, infecção, revisão, Brasil.

\section{Introduction}

The genus Hepatozoon Miller, 1908, is classified in phylum Apicomplexa, suborder Adeleorina, family Hepatozoidae (WENYON, 1926) and was described for the first time by Miller (1908), infecting laboratory rats.

The life cycle of Hepatozoon species is heteroxenous, with merogony followed by gametogony occurring in vertebrate hosts and syngamy and sporogony in hematophagous invertebrate hosts such mosquitoes, fleas, mites and ticks (SMITH, 1996).

The suborder Adeleorina is characterized by development of macro and microgametes (one to four) within a host cell, absence of endodyogeny and formation of oocysts with sporocysts and sporozoites (BARTA, 1989).

The three families that compose Adeleorina are Haemogregarinidae, with the genera Haemogregarina, Desseria and Cyrilia; Karyolysidae, with Karyolysus and Hemolivia; and Hepatozoidae, with a single genus, Hepatozoon (BARTA, 1989). Species of Hepatozoon are distinguished by the formation of large polysporocystic oocysts occurring in the hemocoel of the invertebrate

*Corresponding author: Lucia Helena O’Dwyer

Department of Parasitology, Institute of Biosciences,

Universidade Estadual Paulista - UNESP, Campus de Botucatu,

Distrito de Rubiāo Júnior, 18618-970 Botucatu - SP, Brazil;

e-mail: odwyer@ibb.unesp.br definitive host and transmission to vertebrates via ingestion of the infected invertebrate host (SMITH, 1996). This genus contains hundreds of species infecting birds, reptiles, amphibians and mammals, and it is distributed around all continents. The systematics of many Hepatozoon species remains unclear, since there are few species with a completely described biological cycle (SMITH, 1996) and full genetic characterization.

Domestic dogs are infected by two species, Hepatozoon canis and Hepatozoon americanum, with distinct clinical, pathological, biological and genetic characteristics. The distribution of $H$. canis is widespread, and this species has been reported in Africa, southwestern Asia, southwestern and eastern Europe and North and South America, while Hepatozoon americanum is restricted to the United States (BANETH et al., 2003). In Brazil, so far, the only species described in dogs has been $H$. canis (RUBINI et al., 2005; PALUDO et al., 2005).

\section{History}

Hepatozoon canis was first described in the early 1900s. The first observation of an intraleukocytic parasite of mammals was made by Bentley, in India in 1904, who published a "preliminary 
note upon a leucocytozoan of the dog" (BENTLEY, 1905a,b) Starting from Bentley's information, James (1905a) examined blood from dogs and found the parasite in six out of 45 animals. He made a detailed description of the morphology of the blood parasites and observed that the dogs were little, if at all, affected by the parasites, and were in good health (JAMES, 1905a,b). Until that time, no leukocyte parasites had been described in mammals, only in birds. Since the parasites found had affinities with haemogregarines and represented an entirely unknown parasite, he suggested the name Leucocytozoon canis for the new species (JAMES, 1905a).

Shortly afterwards, Gerrard (1906) described a case of a sick puppy, infected with $L$. canis. He was unable to confirm or deny whether the symptoms presented by the dog resulted from the infection. In addition, this author reported that a health puppy that was placed together with the infected dog became sick and infected with Leucocytozoon. Since there were many ticks on the sick dog and one tick was found on the puppy, he suggested the possibility that ticks were the vectors of this new parasite. He was thus the first to associate ticks with $H$. canis.

Leucocytozoon canis infection has usually been detected in neglected young dogs, which developed severe disease. Developmental forms have been described in the bone marrow of dogs and in the gut of Rhipicephalus sanguineus nymphs removed from heavily infected dogs (CHRISTOPHERS, 1906). Subsequently, Christophers (1907) confirmed that $R$. sanguineus was the invertebrate host of $L$. canis, and described the sexual and asexual cycle in this tick.

Miller (1908) described an intraleukocytic haemogregarine of laboratory rats that underwent gametogenesis and sporogony in the hemocoel of the mite Laelaps echidninus, and named it Hepatozoon perniciosum. This was the first description of the Hepatozoon genus.

Following on from Miller (1908), Wenyon (1910) suggested that the generic name Leucocytozoon should be changed to Hepatozoon, when used for parasites of mammals. Thus, the parasite of leukocytes in dogs had its name changed from L. canis to $H$. canis, and the latter is still used today.

At the beginning of the $20^{\text {th }}$ century, the biological cycle of $H$. canis was studied in ticks (the biological vector), and in the tissues of dogs (CHRISTOPHERS, 1906, 1907, 1912; WENYON, 1911). In ticks, Christophers $(1906,1907)$ distinguished the developmental forms that preceded sexual reproduction. He was the first to suggest that infection occurs after ingestion of the tick, although the author believed that this was an unlikely infection route.

Wenyon (1911) did not observe the conjugation process in the tick gut, but followed the formation of large oocysts $(100 \mathrm{~mm})$, with 30 to 50 sporocysts and 16 sporozoites within the tick hemocoel. This author thought that infection and transmission occurred through adult ticks, but Christophers (1912) proved that the nymph stage acquires the infection from infected dogs, while adults transmit the protozoa.

Subsequently, almost a century passed by before new biological studies were made by Baneth et al. (2007).

Prior to 1997 , only one species (H. canis) was recognized, which infected dogs in Europe, Africa, Asia and the USA (McCULLY et al., 1975; CRAIG et al., 1978; EZEOKOLI et al., 1983; MURATA et al., 1991;
BANETH et al., 1996). The species found in USA was assumed to be a particularly virulent strain of $H$. canis (CRAIG et al., 1978). In 1997, a new species infecting dogs in the United States was recognized: H. americanum (VINCENT-JOHNSON et al., 1997).

The two species, $H$. canis and H. americanum, have different tissue stages, clinical syndromes, host tick vectors and genetic and antigenic characteristics (VINCENT-JOHNSON et al., 1997; BANETH et al., 2000a; EWING et al., 2000). In Brazil, so far only $H$. canis has been detected parasitizing dogs.

\section{Life Cycle of Hepatozoon canis in Domestic Dogs}

After dogs ingest infected ticks, the sporozoites are released from the oocysts, enter the circulation and reach many organs, such as the bone marrow, spleen, liver, kidneys, lungs, intestine and lymph nodes. In a study on experimental infection, the earliest $H$. canis merogony, with a small number of immature meronts, was noted in the bone marrow on the $13^{\text {th }}$ day after infection. On the $26^{\text {th }}$ day after infection, two types of mature meronts were detected: one containing 20-30 micromerozoites arranged at the periphery of the meront, called a "wheel spoke" pattern, and the other with two to four macromerozoites. The micromerozoites were the progenitors of gamonts and the macromerozoites were probably responsible for the development of secondary meronts in the tissues. Gamonts were detected in the peripheral blood on the $28^{\text {th }}$ day after infection and the parasitemia peak occurred 39 days after infection. These gamonts were ellipsoidal, surrounded by a capsule within the leukocyte cytoplasm and frequently seemed to compress the host cell nucleus (BANETH et al., 2007) (Figure 1).

Monozoic cysts were detected in the spleen and contained a curved zoite with a single nucleus. These cysts did not seem to be located within a host cell (BANETH et al., 2007), and they resembled cysts formed by other Hepatozoon species that have been associated with predatory transmission (BANETH; SHKAP, 2003).

In Brazil, O'Dwyer et al. (2004) also observed H. canis tissue stages in naturally infected dogs. Schizonts at various developmental

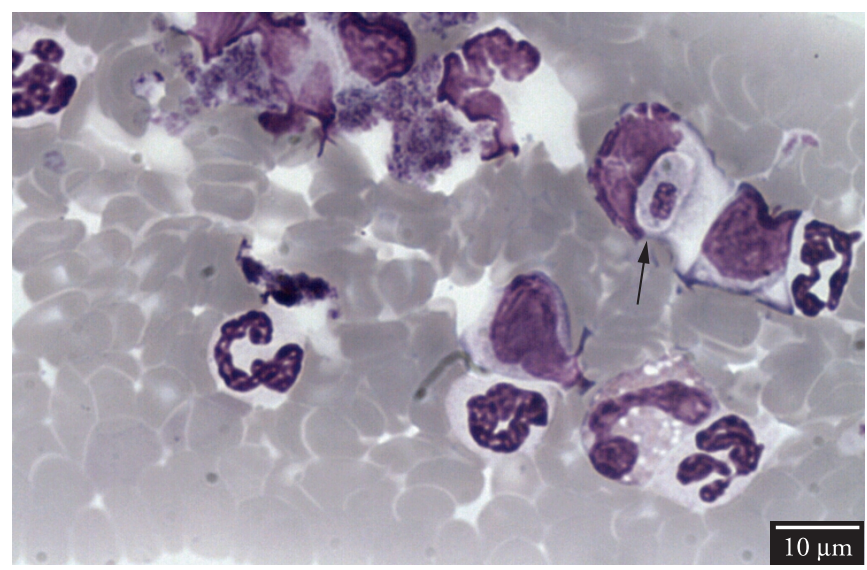

Figure 1. Hepatozoon canis mature gamont in the peripheral blood of a naturally infected dog. Giemsa stain. Photo taken by Lucia Helena O’Dwyer. 
stages and monozoic cysts were found preferentially within the spleen and the bone marrow; nevertheless, no mature meronts were found (Figure 2). The parasite was not found infecting muscles.

\section{Life Cycle of Hepatozoon canis in the Tick Rhipicephalus sanguineus}

The life cycle of $H$. canis in $R$. sanguineus has been studied using two experimental infection methods. In the first one, tick nymphs were fed on a naturally infected $\mathrm{dog}$, and in the second one, nymphs were infected by means of percutaneous injection of infected buffy coat (BANETH et al., 2007). Thirty minutes after percutaneous injection, $H$. canis gamonts were still found within neutrophils in hemolymph smears. Syzygy was observed 24 hours after infection, and early oocysts were detected 96 hours after nymph repletion. Maturation was completed 35 days post-molt to the adult stage, and the oocysts were then infective to dogs. The mature oocysts measured about $260 \times 300 \mathrm{~mm}$, were enveloped in thick membranes and contained multiple sporocysts (range: 57-129), with seven or eight sporozoites (BANETH et al., 2007). This number of sporozoites was lower than the number found by Wenyon (1911), which was 16.

\section{Transmission}

Hepatozoon transmission takes place when dogs ingest ticks containing mature oocysts in the hemocoel. After ingestion, sporozoites are released into the dog's gastrointestinal tract, penetrate the intestinal wall and are transported through the blood to hemolymphatic tissues, including the spleen, bone marrow and lymph nodes, where meronts are formed. Merogony can also take place in other visceral organs, such as the liver, lungs and kidneys. Merozoites released from meronts invade neutrophils or monocytes, in which they develop to form gamonts in the peripheral blood. When ticks take a blood meal from an infected $\mathrm{dog}$, the ingested gamonts are released from the leukocytes in the tick gut, associate in pairs and differentiate to gametes. Fertilization is followed by formation of a zygote, which undergoes a process called sporogony, to form mature oocysts in the tick hemocoel (BANETH et al., 2001, 2003, 2007).

Rhipicephalus sanguineus nymphs acquire the infection after feeding on an infected dog. After transstadial transmission, the tick's adult stage is infective to dogs through oral inoculation (BANETH et al., 2001, 2007).

The tick $R$. sanguineus is considered to be the main vector for $H$. canis (CHRISTOPHERS, 1907, 1912; BANETH; WEIGLER, 1997) and is highly susceptible to infection (BANETH et al., 2001). In one study, oocysts were detected in $85 \%$ of the adult ticks that developed from nymphs fed on infected dogs with a high level of parasitemia (48\%). Nevertheless, it is likely that dogs with lower parasitemia would infect the vector, since the ticks have the ability to concentrate several times their body weight of blood (BANETH et al., 2001).

In the state of Espírito Santo, Brazil, the presence of $R$. sanguineus-infested dogs was associated with $H$. canis infection, both in urban and rural dogs (SPOLIDORIO et al., 2009). However, this association was not found in rural dogs in the state of Rio de Janeiro (O'DWYER et al., 2001). Other tick species have been identified as possible hosts, such as Haemaphysalis flava in Japan (MURATA et al., 1995) and Ixodes ricinus in Italy (GABRIELLI et al., 2010).

In Brazil, depending on the geographical region, dogs from rural areas are infested by different Amblyomma species, including Amblyomma ovale, Amblyomma aureolatum, Amblyomma tigrinum and Amblyomma cajennense (LABRUNA et al., 2000, 2001; LABRUNA; CAMPOS PEREIRA, 2001).

During a study on hepatozoonosis in two rural areas of the state of Rio de Janeiro, Forlano et al. (2005) found Hepatozooninfected dogs that were naturally infested with $A$. cajennense,
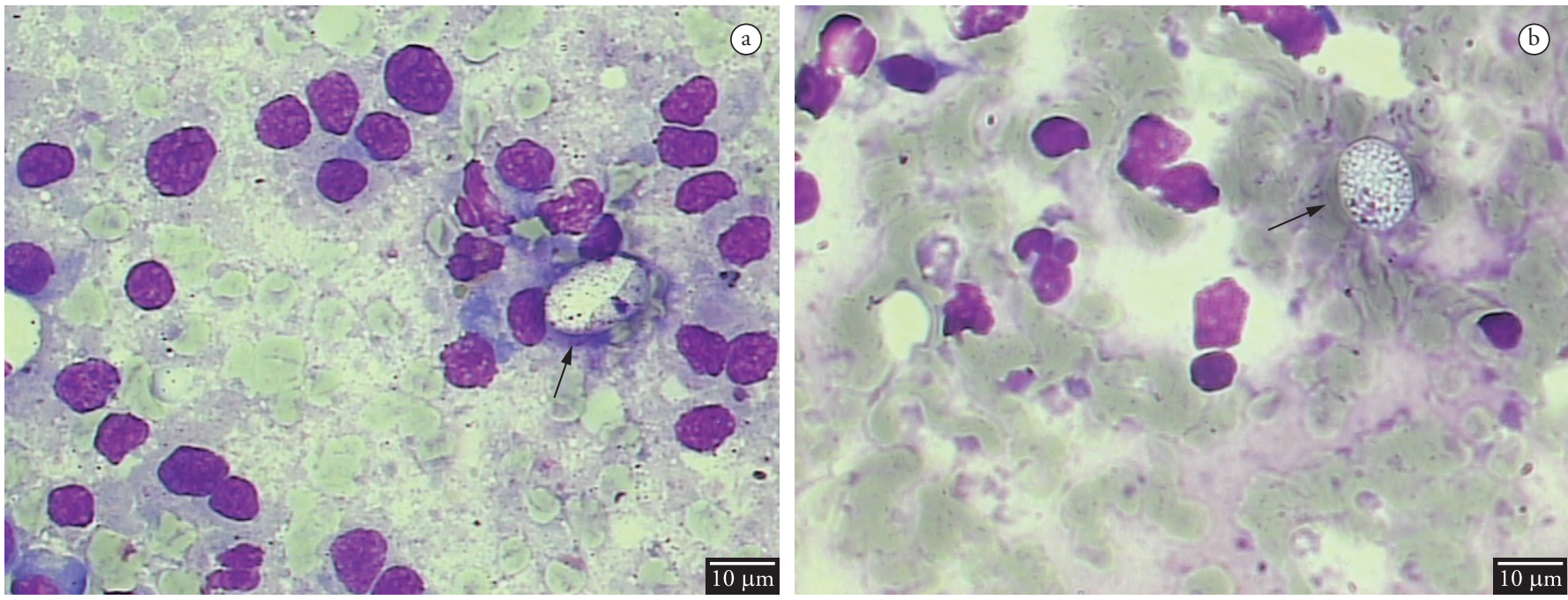

Figure 2. Developmental stages of Hepatozoon canis in the spleen of a naturally infected dog. a) Hepatozoon canis cystlike form. b) Developing meront containing coarse-looking material with no evident nucleus. Giemsa-stained cytological preparation from the spleen. Photo taken by Lucia Helena O’Dwyer. 
A. ovale, A. aureolatum and R. sanguineus. These ticks were collected and searched for the presence of oocysts; only one specimen of A. ovale had oocysts, in the hemocoel, which resembled $H$. canis. A dog that was orally inoculated with macerate of $A$. ovale became infected with the hemoparasite, as demonstrated by gametocytes in the peripheral blood 63 days after inoculation. In another study, Rubini et al. (2009) created an infestation of adult $A$. ovale ticks in dogs that were naturally infected with $H$. canis. Three puppies were orally inoculated with ticks that had been fed on infected dogs, and one of the puppies became positive, with the presence of gametocytes in peripheral blood, after 32 days. Hemolymph smears were prepared from $50 \%$ of the ticks fed on positive dogs. It was found that two females presented oocysts in hemocoel, one and four days after feeding (Figure 3). Both of these studies demonstrated that $A$. ovale may participate as a vector for $H$. canis in rural areas of Brazil. The Brazilian H. canis life cycle can be seen at Figure 4.

During a study to determine the prevalence of hepatozoonosis and its possible tick vectors, in rural dogs in the municipality of Uberlândia, Minas Gerais, Brazil, De Miranda et al. (2011) detected the presence of $H$. canis oocysts in Rhipicephalus (Boophilus) microplus collected from an infected dog. This suggested that this tick species might play a role in the transmission of $H$. canis to dogs, although the extent of this role in the natural cycle of $H$. canis still needs to be evaluated, since the preferred host of R. microplus is cattle and not dogs.

So far, there have not been any reports of the presence of R. sanguineus in Brazil, either naturally or experimentally infected with H. canis (FORLANO et al., 2005; GOMES et al., 2010), although this tick species is considered to be the main vector (BANETH et al., 2007).

Gomes et al. (2010) evaluated H. canis infection in 300 dogs from urban areas of Uberlândia and found that $26 \%$ of the dogs were infested with $R$. sanguineus and $7.66 \%$ were infected with Hepatozoon sp. The ticks were found in $43.5 \%$ of the infected dogs and no significant association was found between tick infestation and $H$. canis infection ( $\mathrm{p}>0.05)$. All ticks collected from the dogs were examined for the presence of $H$. canis oocysts, and no stages of the parasites were found.

In metropolitan Recife, Brazil, $R$. sanguineus was the only species found parasitizing dogs, and this was associated with the low frequency of $H$. canis-infected dogs (0.48\%) (RAMOS et al., 2010).

These negative results found in Brazil, which differed from the observations of Baneth et al. (2007), are likely to be related to differences between $R$. sanguineus in Brazil and in other regions in the world. Oliveira et al. (2005) described morphological differences between specimens of $R$. sanguineus collected in Brazil and Argentina, such as body size and genital pore and sensory structures, thus suggesting that the species found in Brazil may be different. While the mitochondrial $12 \mathrm{~S}$ rDNA sequences of Argentinean ticks were closest to corresponding sequences of $R$. sanguineus from France, the sequences from Brazilian ticks were closest to Rhipicephalus turanicus from Zimbabwe (SZABÓ et al., 2005). Burlini et al. (2010) determined partial sequences for the mitochondrial $12 S$ and 16S rRNA genes of $R$. sanguineus from seven Brazilian states, and performed phylogenetic analyses with the corresponding GenBank sequences of $R$. sanguineus and $R$. turanicus. They found that the sequences from Brazilian ticks grouped with GenBank sequences of $R$. turanicus from Sub-Saharan Africa (Zimbabwe and Zambia), and R. sanguineus from Asia (Thailand and Taiwan). Continuing the phylogenetic studies on ticks belonging to the $R$. sanguineus group, Moraes-Filho et al. (2011) performed analyses based on the mitochondrial 16S rRNA gene of $R$. sanguineus specimens from 29 localities among nine Latin-American countries, plus $R$. sanguineus sensu stricto from South Africa, Spain and Italy and $R$. turanicus from South Africa and Spain. They obtained six different haplotypes and separated the tick sequences into two distinct species: one "tropical" species and other designated as the "temperate" species because of their distribution in the southern portion of South America. All these
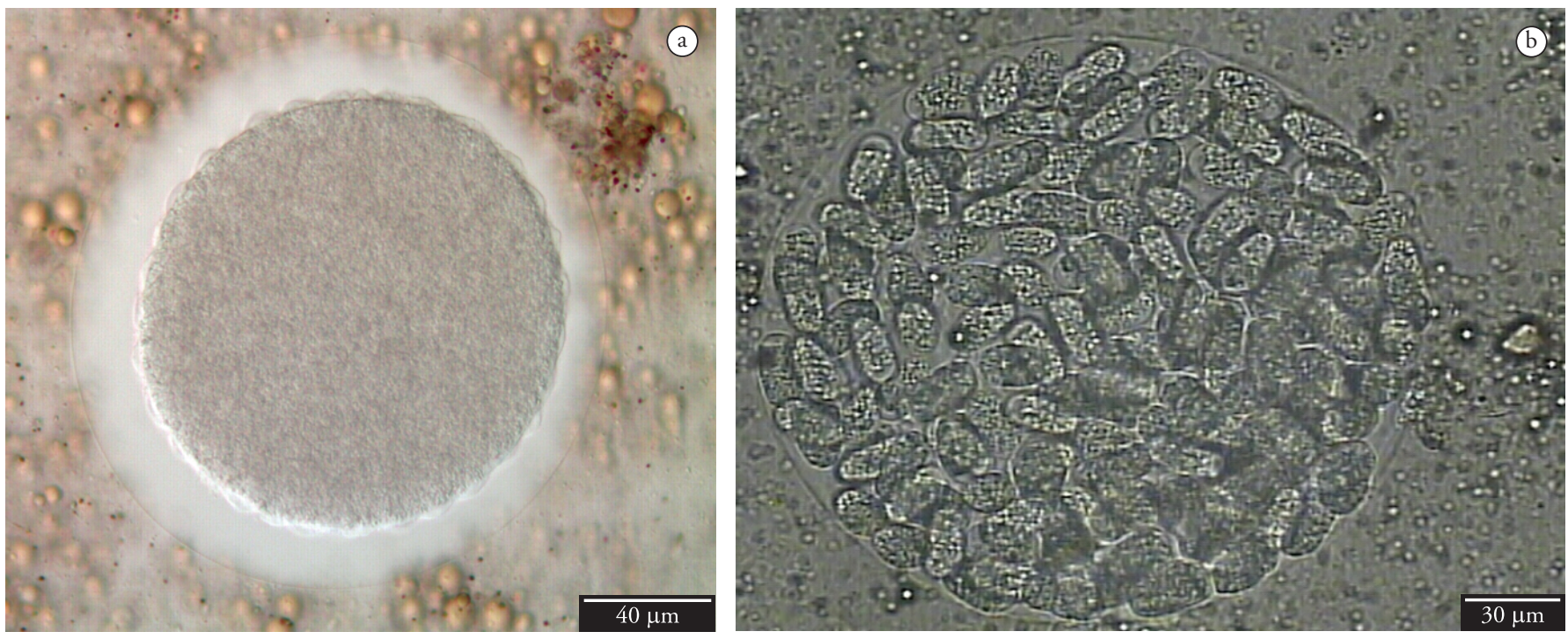

Figure 3. Oocysts of Hepatozoon canis recovered from the hemocoel of experimentally infected Amblyomma ovale ticks. a) Immature oocyst; b) Mature oocyst. Fresh preparation. Photos taken by Adriano Runini. 


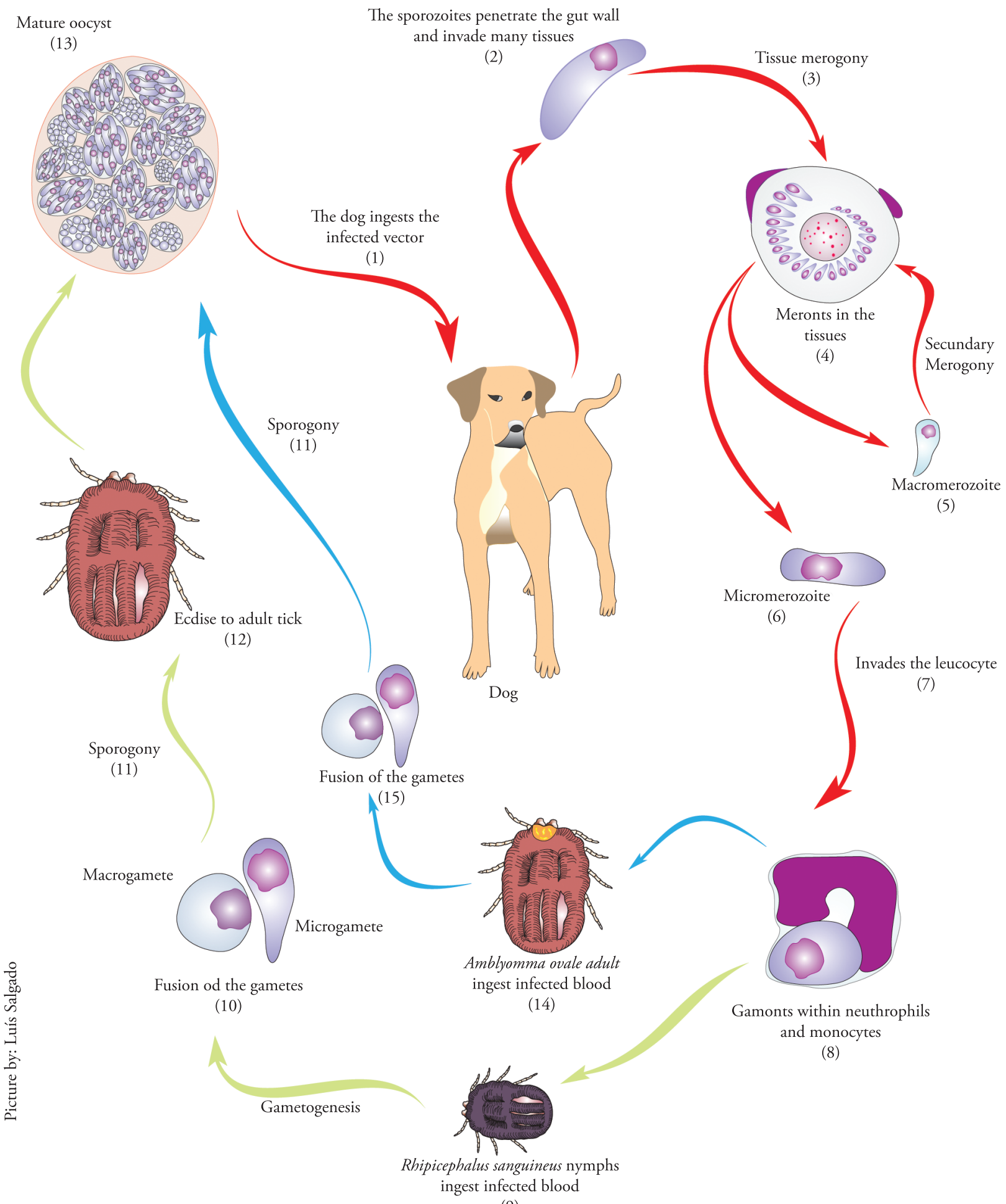

(9)

Figure 4. Hepatozoon canis life cycle. The dog becomes infected by ingesting the tick with mature oocysts within the hemocoel (1). The sporozoites are released from sporocysts and oocysts, penetrate the gut wall and disseminate via circulatory system to the tissues (2). Within the tissue cells the merogony takes place (3) with the meronts formation (4). There are two types of meronts. One forms the macromerozoites (5) which create secondary meronts. The second, forms micromerozoites (6) which invade neutrophils and monocytes (7) and develop into gamonts (8). When a Rhipicephalus sanguineus nymph (9) or an Amblyomma ovale adult (14) ingest infected blood, the gamonts differentiate into macro and microgametes $(10,15)$. After fertilization, the zygote reach the hemocoel and the sporogony takes place (11). The sporogony in $R$. sanguineus is completed only after the molt to adult tick (12), yet in $A$. ovale the sporogony iniciates and finishes within the adult stage (14). The sporogony is completed with the formation of oocysts with many sporocysts in which the infective sporozoites are found (13). 
studies lead to the question of whether the R. sanguineus species from southern Brazil is capable of acquiring and transmitting H. canis.

Predation of paratenic hosts such as rodents, infected with cystozoites of Hepatozoon spp. or infested with the tick vector, are another two modes of transmission among unconfined dogs, as already proved for $H$. americanum (JOHNSON et al., 2007; JOHNSON et al., 2009a,b). These transmission methods should be investigated in relation to $H$. canis in Brazil.

Transmission may also occur vertically, to puppies born from an infected bitch (MURATA et al., 1993b).

\section{Epidemiology}

Hepatozoon canis infection has already been diagnosed in many South American countries like Argentina (EIRAS et al., 2007), Brazil (MASSARD, 1979; MUNDIM et al., 1992; O'DWYER et al., 2001; RUBINI et al., 2005) and Colombia (ARDILA et al., 2007).

In the USA, $H$. americanum is the more prevalent species, although $H$. canis has also been detected in mixed $H$. americanum and $H$. canis infection (ALLEN et al., 2008).

A molecular survey was conducted among dogs in Grenada, in the Caribbean, and 7\% were positive for $H$. canis (YABSLEY et al., 2008).

In Brazil, $H$. canis infection has been reported in many states, including the Federal District (PALUDO et al., 2003), Espírito Santo (MASSARD, 1979; SPOLIDORIO et al., 2009), Goiás (MUNDIM et al., 2008 b), Mato Grosso do Sul (SALGADO, 2006), Minas Gerais (MUNDIM et al., 1992, 1994, 2008a), Rio de Janeiro (MASSARD, 1979; O'DWYER et al., 2001; SÁ et al., 2007), Rio Grande do Sul (MASSARD, 1979; LASTA et al., 2009), Sáo Paulo (GONDIM et al., 1998; RUBINI et al., 2005; O'DWYER et al., 2006) and, most recently, Pernambuco (DANTAS-TORRES et al., 2010; RAMOS et al., 2010). This infection has also been detected in domestic cats: in São Paulo (PEREZ et al., 2004), with molecular characterization demonstrating high similarity with $H$. canis (RUBINI et al., 2006); and in Maranhão, with Hepatozoon DNA showing more similarity with H. felis (DE BORTOLI et al., 2011).

Massard (1979) conducted the first epidemiological study targeting $H$. canis infection in Brazil. The diagnostic method used was blood smears and the infection was more prevalent in dogs from rural areas (31.58\%) than in dogs from urban areas (4.48\%).

In Minas Gerais, two dogs were found infected with mixed H. canis and Ehrlichia canis infection (MUNDIM et al., 1992) and, subsequently, another 22 dogs aged 30 days to 8 years were also found infected with $H$. canis (MUNDIM et al., 1994). Again in Minas Gerais, Mundim et al. (2008a) observed that among 115 infected dogs, 33.9\% were young dogs under one year of age, and that both males (60\%) and females (40\%) could be infected. According to Gomes et al. (2010), dogs of all ages can be infected with $H$. canis, although the prevalence in animals under one year is higher.

In Botucatu, state of São Paulo, Gondim et al. (1998) diagnosed eight $H$. canis-infected dogs ranging in age from two months to 11 years: there were both males and females and they presented concurrent diseases. Subsequently, in the same city, O'Dwyer et al. (2006) found that only 5.9\% (13/222) of the dogs investigated were positive: eight males and five females.

Low prevalence has been detected in many Brazilian cities. Salgado (2006) found that $2.4 \%$ (4/167) of the dogs investigated in the state of Mato Grosso do Sul were infected. The age range was from a few months to nine years. Three of the infected dogs were purebreds and three were female. All these dogs had simultaneous E. canis infection. In Anápolis, state of Goiás, out of $53 \mathrm{dogs}$ examined, infection was detected by blood smear examination in only one (5.56\%) (MUNDIM et al., 2008b). Ramos et al. (2010) studied tick-borne pathogens in dogs in metropolitan Recife, state of Pernambuco, found that only $0.49 \%(1 / 205)$ was infected with $H$. canis, by means of the polymerase chain reaction test (PCR).

High $H$. canis prevalence was found by some authors, when the studies were carried out on dogs from rural areas. In rural areas of the state of Rio de Janeiro, O'Dwyer et al. (2001) examined 250 dogs using blood smear evaluations, and they detected that $39.2 \%$ were infected with $H$. canis. The prevalence of infection in different counties has been found to range from 9.1 to $59.4 \%$, with similar prevalence in different age groups.

Rubini et al. (2008) conducted a molecular and parasitological survey of $H$. canis among 150 rural dogs in the state of São Paulo. Among the dogs examined, 17 (11.3\%) were positive according to blood smear examinations, whereas $80(53.3 \%)$ were positive according to PCR.

High $H$. canis prevalence was also observed by Spolidorio et al. (2009), in dogs in the state of Espírito Santo. Apparently healthy dogs were examined, with an overall infection rate of $58.7 \%$ (54/92). There was no significant association $(\mathrm{p}>0.05)$ between positive dogs from urban or rural households.

In Porto Alegre, state of Rio Grande do Sul, Hepatozoon sp. gamonts were observed in the peripheral blood of a dog, and the sequence confirmed that homology with $H$. canis existed. This was the first molecular detection of $H$. canis in southern Brazil (LASTA et al., 2009).

The different published papers have revealed that, in Brazil, $H$. canis is present in all regions but that its prevalence is quite variable, depending on the state, the origin of the animals (i.e. whether the dogs are from rural or urban areas) and the diagnostic methodology (i.e. blood smears or PCR). The parasite does not discriminate between the sexes or age groups, and it is associated with tick infestation. So far, the data suggest that infection is more common in dogs from rural areas, although some urban dogs have also been found to be infected. It would be of interest to investigate whether the infected dogs in urban areas had already visited rural areas or not.

\section{Clinical Findings}

Since the time of the first descriptions, the pathogenicity of $H$. canis has been a matter for debate (JAMES, 1905a,b). Nowadays, it is accepted that the infection level can vary from subclinical, usually associated with low parasitemia rates, to severe and life-threatening in animals with high parasitemia rates, often in 
puppies or immunosuppressed animals (ELIAS; HOMANS, 1988; BANETH; WEIGLER, 1997).

Hepatozoon canis infection is frequently associated with other pathogens, like Toxoplasma gondii, E. canis, Babesia canis, Mycoplasma haemocanis, Parvovirus and others (HARMELIN et al., 1992; MUNDIM et al., 1992, 1994; BANETH; WEIGLER, 1997; O’DWYER et al., 1997; GONDIM et al., 1998; SASANELLI et al., 2009).

In Brazil, the infection has always been described in naturally infected dogs, frequently with concurrent infections, and the clinical signs and hematological abnormalities described may not be exclusively related to $H$. canis infection.

In Botucatu, state of São Paulo, the clinical signs observed in eight naturally infected dogs included anorexia, weight loss, pale mucous membranes, pain, diarrhea, vomiting, gait abnormalities, fever, polyuria and polydipsia (GONDIM et al., 1998).

In dogs in Brasília, Federal District, the clinical signs cited were similar to the above: anorexia, weight loss and pale mucous membranes (PALUDO et al., 2003, 2005). These were associated with muscle degeneration and atrophy, i.e. similar to the signs caused by $H$. americanum (PALUDO et al., 2005).

In Uberlândia, state of Minas Gerais, the most common clinical signs detected were hyperthermia, anorexia, eye discharges, pale mucous membranes, apathy and diarrhea (MUNDIM et al., 1994, 2008a). While Mundim et al. (2008a) affirmed that the majority of the dogs $(77.4 \%)$ solely presented $H$. canis parasitemia, concurrent infections could not be ruled out, since the infection was only diagnosed by means of blood smear examinations.

In Brazil, most of the infected dogs are asymptomatic and have subclinical infection. This is frequently associated with other infections, especially B. canis vogeli and E. canis infection.

Our experience shows that Brazilian canine hepatozoonosis is often a subclinical infection or mild disease, usually associated with extremely low parasitemia (under 1\% of neutrophils are infected). Regardless of the low pathogenicity of the infection in this country, the data in the literature have demonstrated that in some cases, $H$. canis infection can leads to severe disease that includes muscle lesions, as seen in American canine hepatozoonosis (PALUDO et al., 2005; TSACHEV et al., 2008; MARCHETTI et al., 2009).

\section{Laboratory Findings}

The laboratory findings from $H$. canis-infected dogs can vary as much as the clinical findings do.

The most common hematological abnormalities in $H$. canisinfected dogs, with or without concurrent infection, have been anemia, neutrophilia, hyperglobulinemia and increased alkaline phosphatase and creatinine kinase activities (ELIAS; HOMANS, 1988; IBRAHIM et al., 1989; BANETH; WEIGLER, 1997).

In Brazil, the laboratory abnormalities observed have also been from naturally infected dogs and cannot be exclusively attributed to $H$. canis infection.
In Botucatu, state of São Paulo, Gondim et al. (1998) described anemia, leukocytosis with neutrophilia in three dogs, lymphopenia in three cases and monocytosis in four animals. In serum biochemical tests, the most common abnormalities were increased urea, alkaline phosphatase and creatinine kinase activities.

Mundim et al. (2008a), in Uberlândia, state of Minas Gerais, found that the hematological alterations were normochromicnormocytic anemia in $70.43 \%$ of the dogs, leukocytosis in $39.13 \%$, neutrophilia in $48.70 \%$ and eosinopenia in $40.87 \%$ of the infected dogs.

Paludo et al. (2003), in Brasília, Federal District, and O'Dwyer et al. (2006), in Botucatu, did not find any differences in hematological parameters between the positive and negative dogs, but the dogs examined in both of these studies had low parasitemia.

In Brazil, no experimental studies have been conducted on dogs infected only with $H$. canis, i.e. free from other pathogens. Such studies would determine the clinical findings and hematological abnormalities relating to Brazilian canine hepatozoonosis.

\section{Diagnosis}

\section{Clinical diagnosis}

Clinicians can suspect that $H$. canis infection is present when dogs have fever, anorexia, weight loss, pale mucous membranes, eye discharges and hind limb weakness (ELIAS; HOMANS, 1988; BANETH et al., 1998). However, because these clinical findings are nonspecific, confirmation from laboratory tests is needed.

\section{Laboratory diagnosis}

\subsection{Parasitological diagnosis}

Hepatozoon canis infection is frequently diagnosed by means of blood smear examination, in order to detect gamonts within neutrophils or monocytes (BANETH et al., 2003). The gamonts are large $(11.0 \times 5.0 \mathrm{~mm})$, ellipsoidal in shape, with a capsule and a large and central nucleus (WANER et al., 1994). Both neutrophils and monocytes can be parasitized and undergo morphological modifications caused by the parasite (MAKIMURA; KINJO, 1991; MURATA et al., 1993a).

Bone marrow aspirates may reveal schizonts at different developmental stages, thus allowing antemortem parasitological diagnosis, in dogs with low parasitemia (BANETH et al., 2007). Recently, Otranto et al. (2011) have suggested that cytological evaluation on buffy coat is a more sensitive test than blood smear evaluation.

$H$. canis gamonts appear in the circulation after tissue merogony, and infected dogs may persistently present latent parasitism for long periods of time (BANETH; WEIGLER, 1997). In our practice, we have noticed that infected dogs that are kept tick-free and consequently not exposed to reinfection present highly varying 
parasitemia that sometimes is detectable and sometimes is not. We have noticed that in some infected dogs, the circulating gamonts have disappeared, such that they were not detected in several blood smear examinations or in PCR. Nevertheless, we have not been able to ascertain whether these dogs eliminated the infection or whether the infection persisted with extremely low parasitemia.

Dogs with latent infection, when exposed to concurrent infections or immunosuppression situations, may present reactivation of tissue schizonts, with resulting rises in parasitemia and clinical manifestations (BANETH; WEIGLER, 1997).

Blood smear examinations are an easy and practical diagnostic method, but the morphology and morphometry of the gamonts do not allow differentiation among species. Moreover, this is not a sensitive test, because the gamonts may not be detected when the parasitemia is very low or intermittent (BANETH et al., 1998).

Therefore, other diagnostic methods should be used.

\subsection{Postmortem diagnosis}

The $H$. canis tissue stages can be detected postmortem, after necropsy, through histopathological evaluation or using tissuefragment touch-impression smears (imprints).

Hepatozoon canis merogonic development takes place in various organs, like bone marrow, spleen and liver, but not in muscles. Mature meronts contain micromerozoites arranged at the periphery of the meront, and are called "wheel spoke" meronts (BANETH et al., 2003). Monozoic cysts with a single parasite may also be observed in the spleen and other organs (BANETH; SHKAP, 2003; O’DWYER et al., 2004).

From necropsies on five naturally infected dogs, O'Dwyer et al. (2004) detected gamonts within polymorphonuclear cells, schizonts at various developmental stages and monozoic cysts. All the organs examined (spleen, liver, lungs, heart, kidneys, lymph nodes and bone marrow), with exception of the muscles, were found to be infected, but the spleen and bone marrow were the organs most parasitized. Neither macroscopic lesions nor inflammatory responses were observed in the infected organs.

\subsection{Serological tests}

Detection of $H$. canis antibodies may be very useful when infected dogs have low parasitemia or were recently infected, prior to gamont formation (BANETH et al., 1998). Shkap et al. (1994) described an indirect fluorescence antibody test (IFAT), based on detection of antibodies that were reactive with $H$. canis gamonts. IFAT was able to detect IgM in dogs from 16 to 39 days after infection and IgG 22 to 43 days after infection, thus confirming its applicability as a diagnostic test for seroprevalence studies (BANETH et al., 1996; BANETH et al., 1998; INOKUMA et al., 1999; KARAGENC et al., 2006).

Baneth et al. (2000a) developed a technique for purifying $H$. canis gamonts from peripheral blood neutrophils, thereby enabling assessment of antigenic characteristics by means of western blot analysis. Western immunoblotting of canine anti- $H$. canis and anti- $H$. americanum serum against $H$. canis gamonts confirmed the antigenic differences between the two Hepatozoon species in dogs (BANETH et al., 2000b). These purified gamonts were also used to develop and evaluate an enzyme-linked immunosorbent assay (ELISA) that was sensitive (86\%) and specific (97\%), and comparable to IFAT (GONEN et al., 2004; MYLONAKIS et al., 2005).

Although these serological methods may be valuable for epidemiological studies and for diagnosing infected dogs, they need an antigen source consisting of dogs with extremely high parasitemia, such as the dogs used by Shkap et al. (1994). However, in Brazil, it is extremely rare to find dogs that are heavily infected.

\subsection{Molecular diagnosis}

The first molecular studies on Hepatozoon began in the 1990s, on species that infect snakes (WOZNIAK et al., 1994; SMITH et al., 1999; PERKINS; KELLER, 2001).

Mathew et al. (2000) were the first to sequence the $18 \mathrm{~S}$ rRNA gene of $H$. americanum and $H$. canis, in dogs, and Hepatozoon catesbianae, in bullfrogs, in order to elucidate their phylogenetic relationships. Their findings suggested that there is a sister group relationship between the two species that infect dogs. In the same year, Baneth et al. (2000b) observed that the genetic distance between $H$. americanum and $H$. canis, plus their antigenic differences, supported recognition of these two as distinct species.

PCR for $H$. canis has been utilized in various studies, and it has been shown to be a sensitive diagnostic technique (INOKUMA et al., 2002; CRIADO-FORNELIO et al., 2003; KARAGENC et al., 2006; LI et al., 2008).

Molecular characterization of Hepatozoon species in dogs in Brazil was achieved by Rubini et al. (2005) and Paludo et al. (2005). Rubini et al. (2005) analyzed the partial 18S rRNA gene sequences from the blood of 31 dogs from rural areas of the state of Sáo Paulo and, out of the 21 positive samples, they sequenced the PCR products from eight. The results indicated that the canine Hepatozoon species from Brazil was closed related to Japanese species, which was considered to be $H$. canis (INOKUMA et al., 2002). Paludo et al. (2005) obtained similar results after sequencing samples from three infected dogs in Brasília.

Primer sets designed to amplify Babesia species DNA have also been capable of detecting Hepatozoon species (780 bp). The primer sets PIRO A1 and PIRO B, which were described as being specific for Babesia spp. (JEFFERIES et al., 2003), showed a band that was about 500 bp greater than the Babesia band, and was also able to detect Hepatozoon species (O'DWYER et al., 2009). Similar results were obtained by Oyamada et al. (2005) and Sasaki et al. (2008).

In dogs from rural areas of the state of Rio de Janeiro, Forlano et al. (2007) used two sets of primers (targeting the $18 \mathrm{~S}$ rRNA) to amplify DNA extracted from blood samples of dogs: one set of universal primers, $2867 \mathrm{~F}$ and $2868 \mathrm{R}$ (MATHEW et al., 2000); and the other, designed to be specific for Hepatozoon, Hep F and Hep R (INOKUMA et al., 2002). The Hepatozoon species found in naturally and experimentally infected dogs was efficiently detected only when the genus-specific primer sets was used, and the sequences obtained from DNA extracted from the dogs were aligned with $H$. canis sequences. Also in Rio de Janeiro, but in an urban dog (1/12), Sá et al. (2007) detected $H$. canis infection by means of PCR. 
In the state of Espírito Santo, southeastern Brazil, Spolidorio et al. (2009) sampled the blood from 92 apparently healthy dogs, and 54 (58.7\%) were positive for $H$. canis. All the sequences generated from Hepatozoon-PCR were identical to each other and to the corresponding $18 \mathrm{~S}$ rDNA sequences of $H$. canis.

Recently, Otranto et al. (2011) suggested that PCR on buffy coat and blood is the best diagnostic assay for detecting $H$. canis infection in dogs.

The data in the literature show that within routine clinical practice, the blood smear examination is the diagnostic test of choice, despite its low sensitivity and inability to allow species differentiation. Serological assays are useful, but have low applicability in Brazil, since the antigens for these tests are obtained from dogs with high parasitemia, which is uncommon in this country. Molecular detection has been greatly used in epidemiological studies and species characterization and has high sensitivity. The sequence of positive samples has been enabling species separation.

\section{Treatment}

Many drugs, including imidocarb dipropionate (ID), antibiotics and anticoccidial agents have been used to treat $H$. canis infection in dogs. The drug of choice has long been ID, although the treatment results from this drug have been inconsistent (PASA et al., 2011).

One of the associations used has been ID 5-6 mg. $\mathrm{kg}^{-1}$, administered subcutaneously or intramuscularly, every 14 days until disappearance of the circulating gamonts (BANETH; WEIGLER, 1997). Baneth et al. (2003) suggested that, at the same time, doxycycline at a dose of $10 \mathrm{mg} \cdot \mathrm{kg}^{-1}$ could be administered orally for 21 days to treat concomitant tick-borne infections. Toltrazuril, an anticoccidial agent, was used in infected dogs at a dose of $10 \mathrm{mg} \cdot \mathrm{kg}^{-1}$ orally for six days, and this led to regression of the clinical signs and biological parameters (BEAUFILS et al., 1996). Marchetti et al. (2009) treated an H. canis-infected dog with skeletal involvement and meningoencephalomyelitis, using ID and prednisone, which led to improvement of the clinical condition.

Sasanelli et al. (2010) studied the efficacy of ID for treating $H$. canis infection and demonstrated that this drug failed to eliminate the parasite, based both on parasitological and on molecular evaluation methods.

Recently, Pasa et al. (2011) tried to improve the efficacy of $H$. canis treatment with an association of ID (at a dose of $6 \mathrm{mg} \cdot \mathrm{kg}^{-1}$ subcutaneously twice, 14 days apart) with oral toltrazuril (at $10 \mathrm{mg} \cdot \mathrm{kg}^{-1}$ once daily for the first five treatment days). The overall clinical efficacy of ID with and without toltrazuril was 83.3\% and $66.7 \%$, respectively, and the authors concluded that toltrazuril did not produce any additional benefit for ID therapy.

To date, treatment is frustrating because no therapeutic regimen has been successful in curing the parasitic infection, although clinical recovery has been achieved. It needs to be remembered that all the drugs used in $H$. canis treatment are efficient in eliminating other pathogens, like Babesia, Ehrlichia and coccidia. Therefore, the clinical improvement may be occurring because of elimination of concurrent infection, thereby producing clinical recovery, and not because of action on the parasite. In Brazil, as far as can be seen, there have not been published papers on this subject matter.

\section{Conclusion}

Over the last 100 years, since the first description of $H$. canis infection in dogs, knowledge about this parasite has advanced, with regard to the biological cycle, epidemiology and diagnostic methods. Nevertheless, in Brazil, some characteristics remain unknown, especially regarding vectors and transmission routes. The main vector in Brazil has not been found yet, although $A$. ovale and $R$. (B.) microplus have already been found to be infected. Predation of paratenic hosts is another possible mode of transmission that has not yet been demonstrated in $H$. canis infection, but this has already been observed in relation to $H$. americanum .

The use of molecular tools to diagnosis the infection has been enabling identification of new endemic areas, different strains and phylogenetic characteristics. In Brazil, the number of studies on this subject has been increasing and it is essential to conduct further studies to detect new epidemiological areas and characterize the possible vectors and other transmission patterns. Studies on experimental infection, in dogs that are free of other diseases, are vital for determining the pathogenicity, the clinical signs and the hematological and serum abnormalities that are induced exclusively by the parasite, in cases of both acute and chronic infection. Many questions relating to knowledge about $H$. canis in Brazil still need to be answered in the future.

\section{Acknowledgements}

We are grateful to The São Paulo State Research Foundation (FAPESP) for their financial support for our researches.

\section{References}

ALLEN, K. E. et al. Diversity of Hepatozoon species in naturally infected dogs in the southern United States. Veterinary Parasitology, v. 154, n. 3-4, p. 220-225, 2008. PMid:18485602. http://dx.doi.org/10.1016/j. vetpar.2008.03.027

ARDILA, A. M. et al. Reporte de casos clínicos con Hepatozoon canis en el Centro Médico Quirúrgico Veterinario de la Universidad Cooperativa de Colombia. Revista electrónica de Veterinaria, v. 8, n. 5, p. 1-12, 2007.

BANETH, G. et al. Hepatozoon canis: the prevalence of antibodies and gametocytes in dogs in Israel. Veterinary Research Communications, v. 20, n. 1, p. 41-46, 1996. PMid:8693700. http://dx.doi.org/10.1007/ BF00346576

BANETH, G. et al. Antibody response to Hepatozoon canis in experimentally infected dogs. Veterinary Parasitology, v. 74, n. 2-4, p. 299-305, 1998.

BANETH, G. et al. Genetic and antigenic evidence supports the separation of Hepatozoon canis and Hepatozoon americanum at the species level. Journal of Clinical Microbiology, v. 38, n. 3, p. 1298-1301, 2000a. PMid:10699047. PMCid:88612.

BANETH, G. et al. Antigenic analysis of gamonts of Hepatozoon canis purified from leukocytes. The Journal of Parasitology, v. 86, n. 2, p. 289-294, 2000b. PMid:10780547. http://dx.doi.org/10.1016/S03044017(97)00160-X 
BANETH, G. et al. Transmission of Hepatozoon canis to dogs naturallyfed or percutaneously-injected Rhipicephalus sanguineus ticks. The Journal of Parasitology, v. 87, n. 3, p. 606-611, 2001. PMid:11426725.

BANETH, G. et al. Canine hepatozoonosis: two disease syndromes caused by separate Hepatozoon spp. Trends in Parasitology, v. 19, n. 1, p. 27-31, 2003. http://dx.doi.org/10.1016/S1471-4922(02)00016-8

BANETH, G.; SAMISH, M.; SHKAP, V. Life cycle of Hepatozoon canis (Apicomplexa: Adeleorina: Hepatozoidae) in the tick Rhipicephalus sanguineus and domestic dog (Canis familiaris). The Journal of Parasitology, v. 93, n. 2, p. 283-299, 2007. PMid:17539411. http://dx.doi.org/10.1645/GE-494R.1

BANETH, G.; SHKAP, V. Monozoic cysts of Hepatozoon canis. The Journal of Parasitology, v. 89, n. 2, p. 379-381, 2003. http://dx.doi. org/10.1645/0022-3395(2003)089[0379:MCOHC]2.0.CO;2

BANETH, G.; WEIGLER, B. Retrospective case-control study of hepatozoonosis in dogs in Israel. Journal of Veterinary Internal Medicine, v. 11, n. 6, p. 365-370, 1997. PMid:9470163. http://dx.doi. org/10.1111/j.1939-1676.1997.tb00482.x

BARTA, J. R. Phylogenetic analysis of the class Sporozoea (phylum Apicomplexa Levine, 1970): evidence for the independent evolution of heteroxenous life cycles. The Journal of Parasitology, v. 75, n. 2, p. 195-206, 1989. PMid:2494316. http://dx.doi.org/10.2307/3282766

BEAUFILS, J. P.; MARTIN-GRANEL, J.; JUMELlE, P. H. Hépatozoonose chez le chienet chez le renard: épidemiologie, clinique et traitement. Pratique Médicale et Chirurgicale de l'Animal de Compagnie, v. 31, n. 3, p. 243-253, 1996.

BENTLEY, C. A. Preliminary note upon a Leucocytozoan of the dog. British Medical Journal, v. 1, p. 988, 1905a. PMid:20762087. PMCid:2320053. http://dx.doi.org/10.1136/bmj.1.2314.988

BENTLEY, C. A. A new leucocytozoan of the dog. British Medical Journal, v. 1, n. 2314, p. 1018, 1905b. PMCid:2320060. http://dx.doi. org/10.1136/bmj.1.2314.1018-a

BURLINI, L. et al. Molecular dissimilarities of Rhipicephalus sanguineus (Acari: Ixodidae) in Brazil and its relation with samples throughout the world: is there a geographical pattern? Experimental and Applied Acarology, v. 50, n. 4, p. 361-74, 2010. PMid:19774468. http://dx.doi. org/10.1007/s10493-009-9321-8

CHRISTOPHERS, S. R. Leucocytozoon canis. Scientific Memoirs by Officers of the Medical and Sanitary Departments of the Government of India, v. 26, p. 1-18, 1906.

CHRISTOPHERS, S. R. The sexual cycle of Leucocytozoon canis in the tick. Scientific Memoirs by Officers of the Medical and Sanitary Departments of the Government of India, v. 28, p. 1-14, 1907.

CHRISTOPHERS, S. R. The development of Leucocytozoon canis in the tick with a reference to the development of Piroplasma. Parasitology, v. 5, n. 1, p. 37-48, 1912. http://dx.doi.org/10.1017/S0031182000000068

CRAIG, T. M. et al. Hepatozoon canis infection in dogs: clinical, radiographic and hematologic findings. Journal of American Veterinary Medical Association, v. 173, n. 8, p. 967-972, 1978. PMid:721677.

CRIADO-FORNELIO, A. et al. Molecular studies on Babesia, Theileria and Hepatozoon in southern Europe: Part I. Epizootiological aspects. Veterinary Parasitology, v. 113, n. 3-4, p. 189-201, 2003. http://dx.doi. org/10.1016/S0304-4017(03)00078-5

DANTAS-TORRES, F. et al. Cutaneous and visceral leishmaniasis in dogs from a rural community in northeastern Brazil. Veterinary
Parasitology, v. 170, n. 3-4, p. 313-317, 2010. PMid:20227186. http://dx.doi.org/10.1016/j.vetpar.2010.02.019

DE BORTOLI, C. P. et al. Molecular characterization of Hepatozoon sp. in cats from São Luís Island, Maranhão, Northeastern Brazil. Parasitology Research, 2011. http://dx.doi.org/10.1007/s00436-011-2376-6

DE MIRANDA, R. L. et al. Oocysts of Hepatozoon canis in Rhipicephalus (Boophilus) microplus collected from a naturally infected dog. Veterinary Parasitology, v. 177, n. 3-4, p. 392-396. 2011. PMid:21324597. http://dx.doi.org/10.1016/j.vetpar.2011.01.044

EIRAS, D. F. et al. First molecular characterization of canine hepatozoonosis in Argentina: evaluation of asymptomatic Hepatozoon canis infection in dogs from Buenos Aires. Veterinary Parasitology, v. 149, n. 3-4, p. 275-279, 2007. PMid:17720320. http://dx.doi. org/10.1016/j.vetpar.2007.07.010

ELIAS, E.; HOMANS, P. A. Hepatozoon canis infection in dogs: clinical and haematological findings treatment. Journal of Small Animal Practice, v. 29, n. 1, p. 55-62, 1988. http://dx.doi. org/10.1111/j.1748-5827.1988.tb02264.x

EWING S. A. et al. American canine hepatozoonosis: an emerging disease in the New World. Annals of the New York Academy of Sciences, v. 916, p. 81-92, 2000. http://dx.doi.org/10.1111/j.1749-6632.2000.tb05277.x

EZEOKOLI, C. D. et al. Clinical and epidemiological studies on canine hepatozoonosis in Zaria, Nigeria. Journal ofSmall Animal Practice, v. 24, n. 7, p. 455-460, 1983. http://dx.doi.org/10.1111/j.1748-5827.1983. tb00385.x

FORLANO, M. et al. Diagnosis of Hepatozoon spp. in Amblyomma ovale and its experimental transmission in domestic dogs in Brazil. Veterinary Parasitology, v. 134, n. 1-2, p. 1-7, 2005. PMid:16081219. http://dx.doi.org/10.1016/j.vetpar.2005.05.066

FORLANO, M. D. et al. Molecular characterization of Hepatozoon sp. from Brazilian dogs and its phylogenetic relationship with other Hepatozoon spp. Veterinary Parasitology, v. 145, n. 1-2, p. 21-30, 2007. PMid:17134837. http://dx.doi.org/10.1016/j.vetpar.2006.10.023

GABRIELLI, S. et al.The first report of Hepatozoon canis identified in Vulpes vulpes and ticks from Italy. Vector-Borne and Zoonotic Diseases, v. 10, n. 9, p. 855-859, 2010. PMid:20420538. http://dx.doi. org/10.1089/vbz.2009.0182

GERRARD, P. N. On a protozoan parasite found in the polymorphonuclear leucocytes of a dog. Journal of Hygiene, v. 6, n. 3, p. 229-230, 1906. http://dx.doi.org/10.1017/S0022172400002862

GOMES, P. V. et al. Occurrence of Hepatozoon sp. in dogs in the urban area originating from a municipality in southeastern Brazil. Veterinary Parasitology, v. 174, n. 1-2, p. 155-161, 2010. PMid:20810218. http://dx.doi.org/10.1016/j.vetpar.2010.07.020

GONDIM, L. F. P. et al. Canine hepatozoonosis in Brazil: description of eight naturally occurring cases. Veterinary Parasitology, v. 74, n. 2-4, p. 319-323, 1998. http://dx.doi.org/10.1016/S0304-4017(96)01120-X

GONEN, L. et al. An enzyme-linked immunosorbent assay for antibodies to Hepatozoon canis.Veterinary Parasitology,v. 122, n. 2, p. 131-139, 2004. PMid:15177718. http://dx.doi.org/10.1016/j. vetpar.2004.03.021

HARMELIN, A. et al. Concurrent Hepatozoon canis and Toxoplasma gondii infections in a dog. Veterinary Parasitology, v. 43, n. 1-2, p. 131-136, 1992. http://dx.doi.org/10.1016/0304-4017(92)90055-E 
IBRAHIM, N. D. G.; RAHAMATHULLA, P. M.; NJOKU, C. O. Neutrophil myeloperoxidase deficiency associated with canine hepatozoonosis. International Journal for Parasitology, v. 19, n. 8, p. 915-918, 1989. http://dx.doi.org/10.1016/0020-7519(89)90119-7

INOKUMA, H. et al. Analysis of the $18 \mathrm{~S}$ rRNA gene sequence of a Hepatozoon detected in two Japanese dogs. Veterinary Parasitology, v. 106 , n. 3, p. $265-271,2002$. http://dx.doi.org/10.1016/S03044017(02)00065-1

INOKUMA, N. D. G.; OHNO, K.; YAMAMOTO, S. Serosurvey of Ehrlichia canis and Hepatozoon canis infection in dogs in Yamaguchi Prefecture, Japan. The Journal of Veterinary Medical Science, v. 61, n. 10, p. 1153-1155, 1999. PMid:10563295. http://dx.doi.org/10.1292/ jvms.61.1153

JAMES, S. P. On a parasite found in the white corpuscles of the blood of dogs. Scientific Memoirs by officers of the Medical and Sanitary Departments of the Government of India, v. 14, p. 1-13, 1905 a.

JAMES, S. P. A new leucocytozoon of dogs. British Medical Journal, v. 1, n. 2320, p. 1361, 1905b. PMCid:2320815. http://dx.doi.org/10.1136/ bmj.1.2320.1361

JEFFERIES, R. et al. Two species of canine Babesia in Australia: Detection and characterization by PCR. Journal of Parasitology, v. 89, n. 2, p. 409-412, 2003. http://dx.doi.org/10.1645/00223395(2003)089[0409:TSOCBI]2.0.CO;2

JOHNSON, E. M. et al. Field survey of rodents for Hepatozoon infections in an endemic focus of American canine hepatozoonosis. Veterinary Parasitology, v. 150, n. 1-2, p. 27-32, 2007. PMid:17942230. http:// dx.doi.org/10.1645/0022-3395(2003)089[0409:TSOCBI]2.0.CO;2

JOHNSON, E. M. et al. Alternate pathway of infection with Hepatozoon americanum and the epidemiologic importance of predation. Journal of Veterinary Internal Medicine, v. 23, n. 6, p. 1315-1318, 2009a. PMid:19709355. http://dx.doi.org/10.1111/j.1939-1676.2009.0375.x

JOHNSON, E. M. et al. Experimental transmission of Hepatozoon americanum to New Zealand White rabbits (Oryctolagus cuniculus) and infectivity of cystozoites for a dog. Veterinary Parasitology, v. 164, n. 2-4, p. 162-166, 2009b. PMid:19559533. http://dx.doi. org/10.1016/j.vetpar.2009.05.028

KARAGENC, T. I. et al. A parasitological, molecular and serological survey of Hepatozoon canis infection in dogs around the Aegean Coast of Turkey. Veterinary Parasitology, v. 135, n. 2, p. 113-119, 2006. PMid:16229952. http://dx.doi.org/10.1016/j.vetpar.2005.08.007

LABRUNA, M. B.; CAMPOS PEREIRA, M. Carrapato em cães no Brasil. Clínica Veterinária, n. 30, p. 24-32, 2001.

LABRUNA, M. B. et al. Ticks (Acari: Ixodidae) associated with rural dogs in Uruará eastern Amazon, Brazil. Journal of Medical Entomology, v. 37, n. 5, p. 774-776, 2000. PMid:11004794. http://dx.doi.org/10.1603/0022-2585-37.5.774

LABRUNA, M. B. et al. Prevalência de carrapatos em cães de áreas rurais da região norte do Estado do Paraná. Arquivo Brasileiro de Medicina Veterinária e Zootecnia, v. 53, n. 5, p. 553-556, 2001. http://dx.doi. org/10.1590/S0102-09352001000500007

LASTA, C. S. et al. Infecção por Hepatozoon canis em canino doméstico na região Sul do Brasil confirmada por técnicas moleculares. Ciência Rural, v. 39, n. 7, p. 2135-2140, 2009. http://dx.doi.org/10.1590/ S0103-84782009005000160
LI, Y. et al. Diagnosis of canine Hepatozoon spp. infection by quantitative PCR. Veterinary Parasitology, v. 157, n. 1-2, p. 50-58, 2008. PMid:18774228. http://dx.doi.org/10.1016/j.vetpar.2008.06.027

MAKIMURA, S.; KINJO, H. Cytochemical identification of canine circulating leucocytes parasitized by the gametocyte of Hepatozoon canis. The Journal of Veterinary Medical Science, v. 53, n. 5, p. 963-965, 1991. PMid:1836390. http://dx.doi.org/10.1292/ jvms. 53.963

MARCHETTI, V. et al. Hepatozoonosis in a dog with skeletal involvement and meningoencephalomyelitis. Veterinary Clinical Pathology, v. 38, n. 1, p. 121-125, 2009. PMid:19228365. http://dx.doi.org/10.1111/j.1939-165X.2008.00080.x

MASSARD, C. A. Hepatozoon canis (JAMES, 1905) (Adeleida: Hepatozoidae) de cáes do Brasil, com uma revisáo do gênero em membros da ordem carnívora. 1979. 121f. Dissertação (Mestradoem Medicina Veterinária - Parasitologia Veterinária)-Faculdade de Medicina Veterinária, Universidade Federal Rural,Rio de Janeiro.

MATHEW, J. S. et al. Phylogenetic relationships of Hepatozoon (Apicomplexa: Adeleorina) based on molecular, morphologic, and life-cycle characters. The Journal of Parasitology, v. 86, n. 2, p. 366-372, 2000. PMid:10780559.

McCULLY, R. M. et al. Observations on naturally acquired hepatozoonosis of wild carnivores and dogs in the Republic of South Africa. Onderstepoort Journal of Veterinary Research,v. 42, n. 4, p. 117-134, 1975. PMid:1221330.

MILLER, W. W. Hepatozoon perniciosum (n.g.; n.sp.); a haemogregarine pathogenic for white rats; with a description of the sexual cycle in the intermediate host, a mite (Lelaps echidninus Berlese). Hygiene Laboratory Bulletin, v. 46, p. 51-123, 1908.

MORAES-FILHO, J. et al. Genetic analysis of ticks belonging to the Rhipicephalus sanguineus group in Latin America. Acta Tropica, v. 117, n. 1, p. 51-55, 2011. PMid:20858451. http://dx.doi.org/10.1016/j. actatropica.2010.09.006

MUNDIM, A. V. et al. Hepatozoon canis (James, 1905) em cães de Uberlândia, Minas Gerais. Relato de dois casos. Brazilian Journal of Veterinary Research and Animal Science, v. 29, p. 359-361, 1992. Suplemento.

MUNDIM, A. V. et al. Hepatozoon canis: estudo retrospectivo de 22 casos de infecção natural em cães de Uberlândia, MG. Revista do Centro de Ciências Biomédicas da Universidade Federal de Uberlândia,v. 10, n. 1, p. 89-95, 1994.

MUNDIM, A. V. et al. Clinical and hematological signs associated with dogs naturally infected by Hepatozoon sp. and with other hematozoa. A retrospective study in Uberlândia, Minas Gerais, Brazil. Veterinary Parasitology, v. 153, n. 1-2, p. 3-8, 2008a. PMid:18304739. http://dx.doi.org/10.1016/j.vetpar.2008.01.018

MUNDIM, E. C. S. et al. Incidência de hemoparasitoses em cães (Canis familiaris) de rua capturados pelo Centro de Controle de Zoonoses (CCZ) da cidade de Anápolis-GO. Ensaios e Ciência, v. 12, n. 2, p. $107-115,2008$ b.

MURATA, T. et al. First case of Hepatozoon canis infection of a dog in Japan. TheJournal of Veterinary Medical Science, v. 53, n. 6, p. 1097-1099, 1991. PMid:1790224. http://dx.doi.org/10.1292/ jvms.53.1097

MURATA, T. et al. Ultrastructure and cytochemical characteristics of leukocyte infected with Hepatozoon canis. The Journal of Veterinary 
Medical Science,v. 55, n. 6, p. 1043-1045,1993a. PMid:8117804. http://dx.doi.org/10.1292/jvms.55.1043

MURATA, T. et al. Vertical transmission of Hepatozoon canis in dogs. The Journal of Veterinary Medical Science, v. 55, n. 5, p. 867-868, 1993 b. PMid:8286548. http://dx.doi.org/10.1292/jvms.55.867

MURATA, T. et al. Detection of Hepatozoon canis oocyst from ticks collected from the infected dogs. The Journal of Veterinary Medical Science, v. 57, n. 1, p. 111-112, 1995. PMid:7756400. http://dx.doi. org/10.1292/jvms.57.111

MYLONAKIS, M. E. et al. Anti- Hepatozoon canis serum antibodies and gamonts in naturally-occurring canine monocytic ehrlichiosis. Veterinary Parasitology, v. 129, n. 3-4, p. 229-233, 2005. PMid:15845277. http://dx.doi.org/10.1016/j.vetpar.2005.01.012

O'DWYER, L. H. et al. Tissue stages of Hepatozoon canis in naturally infected dogs from São Paulo state, Brazil. Parasitology Research, v. 94, n. 3, p. 240-242, 2004.

O'DWYER, L. H. et al. Prevalence, hematology and serum biochemistry in stray dogs naturally infected by Hepatozoon canis in São Paulo. Arquivo Brasileiro de Medicina Veterinária e Zootecnia, v. 58, n. 4, p. $688-690,2006$.

O'DWYER, L. H. et al. Babesia spp. infection in dogs from rural areas of São Paulo state, Brazil.Brazilian Journal of Veterinary Parasitology, v. 18, n. 2 , p. $23-26,2009$.

O'DWYER, L. H.; GUIMARÃES, L.; MASSARD, C. L. Ocorrência de infecção múltipla por Babesia canis, Hepatozoon canis e Haemobartonella canis em um cáo esplenectomizado. Revista Brasileira de Ciência Veterinária, v. 4, n. 2, p. 83-84, 1997.

O'DWYER, L. H.; MASSARD, C. L.; PEREIRA DE SOUZA, J. C. Hepatozoon canis infection associated with dog ticks of rural áreas of Rio de Janeiro State, Brazil. Veterinary Parasitology, v. 94, n. 3, p. 143-150, 2001. http://dx.doi.org/10.1016/S0304-4017(00)00378-2

OLIVEIRA, P. R. et al. Comparison of the external morphology of Rhipicephalus sanguineus (Latreille, 1806) (Acari: Ixodidae) ticks from Brazil and Argentina. Veterinary Parasitology, v. 129, n. 1-2, p. 139-147, 2005. PMid:15817214. http://dx.doi.org/10.1016/j. vetpar.2005.01.001

OTRANTO, D. et al. Diagnosis of Hepatozoon canis in young dogs by cytology and PCR. Parasites and Vectors, v. 4, p. 55-60, 2011. http://dx.doi.org/10.1186/1756-3305-4-55

OYAMADA, M. et al. Detection of Babesia canis rossi, B. canis vogeli, and Hepatozoon canis in dogs in a Village of Eastern Sudan by using a screening PCR and sequencing methodologies. Clinical and Diagnostic Laboratory Immunology, v. 12, n. 11, p. 1343-1346, 2005. PMid:16275954. PMCid:1287771.

PALUDO, G. R. et al. Hepatozoon spp.: report of some cases in dogs in Brasília, Brazil. Veterinary Parasitology, v. 118, n. 3-4, p. 243-248, 2003. PMid:14729172. http://dx.doi.org/10.1016/j. vetpar.2003.10.009

PALUDO, G. R. et al. Hepatozoon spp. : pathological and partial 18S rRNA sequence analysis from three Brazilian dogs. Parasitology Research, v. 97, n. 2, p. 167-170, 2005. PMid:15988602. http://dx.doi. org/10.1007/s00436-005-1419-2

PASA, S. et al. Failure of combination therapy with imidorcarb dipropionate and toltrazuril to clear Hepatozoon canis infection. Parasitology Research, 2011. http://dx.doi.org/10.1007/s0043011.2334-3
PEREZ, R. R.; RUBINI A. S.; O'DWYER. L. H. The first report of Hepatozoon spp. (Apicomplexa: Hepatozoidae) in domestic cats from São Paulo state, Brazil. Parasitology Research, v. 94, n. 2, p. 83-85, 2004. PMid:15290247. http://dx.doi.org/10.1007/s00436-004-1167-8

PERKINS, S. L.; KELLER, A. K. Phylogeny of nuclear small subunit rRNA genes of hemogregarines amplified with specific primers. The Journal of Parasitology, v. 87, n. 4, p. 870-876, 2001. PMid:11534653.

RAMOS, R. et al. Molecular survey and genetic characterization of tick-borne pathogens in dogs in metropolitan Recife (north-eastern Brazil). Parasitology Research, v. 107, n. 5, p. 1115-1120, 2010. PMid:20680344. http://dx.doi.org/10.1007/s00436-010-1979-7

RUBINI, A. S. et al. Molecular identification and characterization of canine Hepatozoon species from Brazil. Parasitology Research, v. 97, n. 2, p. 91-93, 2005. PMid:15948009. http://dx.doi.org/10.1007/ s00436-005-1383-x

RUBINI, A. S. et al. Molecular characterization of feline Hepatozoon species from Brazil. Veterinary Parasitology, v. 137, n. 1-2, p. 168-171, 2006. PMid:16448756. http://dx.doi.org/10.1016/j. vetpar.2005.12.008

RUBINI, A. S. et al. Molecular and parasitological survey of Hepatozoon canis (Apicomplexa: Hepatozoidae) in dogs from rural area of Sao Paulo state, Brazil. Parasitology Research, v. 102, n. 5, p. 895-899, 2008. PMid:18188597. http://dx.doi.org/10.1007/s00436-007-0846-7

RUBINI, A. S. et al. Acquisition and transmission of Hepatozoon canis (Apicomplexa: Hepatozoidae) by the tick Amblyomma ovale (Acari: Ixodidae). Veterinary Parasitology, v. 164, n. 2-4, p. 324-327, 2009. PMid:19501969. http://dx.doi.org/10.1016/j.vetpar.2009.05.009

SÁ, A. G. et al. Detection of Hepatozoon spp. in naturally infected brazilian dogs by Polymerase Chain Reaction. The International Journal of Applied Research inVeterinary Medicine, v. 5, n. 2, p. 49-51, 2007.

SALGADO, F. P. Identificaçáo de hemoparasitos e carrapatos de cães procedentes do Centro de Controle de Zoonoses de Campo Grande, estado do Mato Grosso do Sul, Brasil. 2006. Dissertação (Mestrado)Universidade Federal do Mato Grosso do Sul, Campo Grande.

SASAKI, M. et al. PCR-based epidemiological survey of Hepatozoon canis in dogs in Nigeria. The Journal of Veterinary Medical Science, v. 70, n. 7, p. 743-745, 2008. PMid:18685252. http://dx.doi.org/10.1292/ jvms. 70.743

SASANELLI, M. et al. Atypical clinical presentation of coinfection with Ehrlichia, Babesia and Hepatozoon species in a dog. The Veterinary Record, v. 164, n. 1, p. 22-23, 2009. PMid:19122221. http://dx.doi. org/10.1136/vr.164.1.22

SASANELLI, M. et al. Failure of imidocarb dipropionate to eliminate Hepatozoon canis in naturally infected dogs based on parasitological and molecular evaluation methods. Veterinary Parasitology, v. 171, n. 3-4, p. 194-199, 2010. PMid:20444549. http://dx.doi.org/10.1016/j. vetpar.2010.03.042

SHKAP, V.; BANETH, G.; PIPANO, E. Circulating antibodies to Hepatozoon canis demonstrated by immune fluorescence. Journal of Veterinary Diagnostic Investigation, v. 6, n. 1, p. 121-123, 1994. PMid:8011770. http://dx.doi.org/10.1177/104063879400600127

SMITH, T. G. The genus Hepatozoon (Apicomplexa: Adeleina). The Journal of Parasitology, v. 82, n. 4, p. 565-585, 1996. PMid:8691364. http://dx.doi.org/10.2307/3283781

SMITH, T. G.; KIM, B.; DESSER, S. S. Phylogenetic relationships among Hepatozoon species from snakes, frogs and mosquitoes of 
Ontario, Canada, determined by ITS- 1 nucleotide sequences and lifecycle, morphological and developmental characteristics. International Journal for Parasitology, v. 29, n. 2, p. 293-304, 1999. http://dx.doi. org/10.1016/S0020-7519(98)00198-2

SPOLIDORIO, M. G. et al. Hepatozoon canis infecting dogs in the state of Espírito Santo, southeastern Brazil. Veterinary Parasitology, v. 163, n. 4, p. 357-361, 2009. PMid:19482427. http://dx.doi.org/10.1016/j. vetpar.2009.05.002

SZABÓ, M. P. et al. Biological and DNA evidence of two dissimilar populations of the Rhipicephalus sanguineus tick group (Acari: Ixodidae) in South America. Veterinary Parasitology, v. 130, n. 1-2, p. 131-140, 2005. PMid:15893080. http://dx.doi.org/10.1016/j. vetpar.2005.03.008

TSACHEV, I. et al. Clinical Ehrlichia canis and Hepatozoon canis co-infection in a dog in Bulgaria. Revue de MédecineVétérinaire, v. 159, n. 2, p. 68-73, 2008.

VINCENT-JOHNSON, N. A. et al. A new Hepatozoon species from dogs: description of the causative agent of canine hepatozoonosis in North America. The Journal of Parasitology, v. 83, n. 6, p. 1165-1172, 1997. PMid:9406796. http://dx.doi.org/10.2307/3284379

WANER, T. et al. Hepatozoon canis: size measurement of the gametocyte using image analysis technology. Comparative Haematology
International, v. 4, n. 3, p. 177-179, 1994. http://dx.doi.org/10.1007/ BF00798361

WENYON, C. M. Some remarks on the genus Leucocytozoon. Parasitology, v. 3, n. 1,p. 63-72, 1910. http://dx.doi.org/10.1017/ S0031182000001931

WENYON, C. M. Oriental sore in Bagdad, together with observation on a gregarine in Stegomia fasciata, the haemogregarine of dogs and the flagellates of house flies. Parasitology, v. 4, n. 3, p. 273-344, 1911. http://dx.doi.org/10.1017/S0031182000002730

WENYON, C. M. Protozoology: a manual for medical men, veterinarians and zoologists. New York: Wood, 1926.

WOZNIAK, E. J.; TELFORD JUNIOR; S. R.; MCLAUGHLIN, G. L. Employment of the Polymerase chain reaction in the molecular differentiation of reptilian hemogregarines and its application to preventative zoological medicine. Journal of Zoo and Wildlife Medicine, v. 25, n. 4, p. 538-547, 1994.

YABSLEY, M. J. et al. Prevalence of Ehrlichia canis, Anaplasma platys, Babesia canis vogeli, Hepatozoon canis, Bartonella vinsonii berkhoffii, and Rickettsia spp. in dogs from Grenada. Veterinary Parasitology, v. 151, n. 2-4, p. 279-285, 2008. PMid:18160223. http://dx.doi.org/10.1016/j. vetpar.2007.11.008 